\title{
1. Revolutions in the Middle East and Northern Africa
}

\subsection{SOME REMARKS ON REVOLUTIONS}

As we argued in the Introduction, the concept of revolution has reemerged in political theory as a result of the 'Color Revolutions' in some nations of the former Soviet Union and - our concern here - as a result of some of the events known, perhaps inaccurately in retrospect, as the Arab Spring. As we saw, Arendt defined violence as conceptually necessary for a revolution. The events of the Arab Spring suggest that in part because of the development of new information and communication technologies such as Twitter, Facebook, and similar social media revolutions can now occur without violence on the revolutionaries' part. The forces of the existing regime may of course respond to revolutionary challenges with violence, and the revolutionaries may anticipate that result. But, we believe, responsive violence of that sort was not what Arendt built into her definition of revolution.

New information and communication and technologies have facilitated the access revolutionaries have to support in the form of encouragement from around the world, and thereby opened new possibilities for sharing revolutionary ideas and ideals globally. Internet platforms and the new ad hoc e-devices allowed an international non-stop monitoring of the events. This constant and non-stop flow of information allowed the international community to orchestrate and legitimate the imposition of international measures to prevent or condemn responsive violence by the challenged regimes. And, because initiating violent action can discredit those who use violence (in the eyes of an international community whose support may be critical for success), the elimination of violence as a conceptual component of revolution strengthens the revolutionaries' hands as compared to the situations Arendt described. Of course, responsive violence may transform the revolution into a war, as occurred in Libya and Syria. The important point is that the new information and communication technologies place the responsibility for violence in the regime's hands. 
Yet, whether modern revolutions are really non-violent is a question, not a proposition or definition. Sometimes violence - defined as the intentional use of physical force or power, threatened or actual - has been used with revolutionary purposes. Indeed, even if a revolution began with, pursued, and terminated with solely non-violent techniques, we still would have to ask whether the revolutionaries' discourse justified or promoted violent means.

Non-violent methods are varied and diverse, ranging from demonstrations to strikes, from formal statements to symbolic public acts, public assemblies, methods of non-social, non-political or non-economic cooperation or methods of non-violent intervention. ${ }^{37}$ Mobile phones, tablets, and other information and communication technology tools facilitate non-violent movements. These tools increase exponentially the possibilities of non-violent means, and so change the logic of revolutions.

As we have noted, one way the new technologies have facilitated non-violent revolutions is by allowing the use of the internet access to open the possibility of creating a global community for the revolutionaries. Political protests and demonstrations in Tahrir Square were recorded with mobile phones, digital multimedia broadcasters, digital multimedia players (MP3, MP4), and other digital devices. This live broadcast and uncensored data was transmitted by the regular international media stations (Al Jazeera, CNN, BBC, and others), but also by the internet platforms and the new ad hoc devices, such as the crowdsourced crisis maps. ${ }^{38}$

These new technologies distinguish the Arab Spring from other nonviolent processes such as the classic Gandhian movement and even the 'Color Revolutions'. The distinctive feature is not that political demonstrations and protests were orchestrated and channeled in the major internet social networks (Facebook and Twitter), itself a completely new way to set up a revolution, but that these devices found the way to spread

37 Gene Sharp, The Politics of Nonviolent Action, Vol. 2: The Methods of Nonviolent Action (Porter Sargent Publishers 1973).

38 The Libya Crisis Map was a joint initiative of the United Nations Office for the Coordination of Humanitarian Affairs and the Standby Task Force, an online network. The Libya Crisis Map highlighted live information relevant to relief efforts such as health needs, security threats, and displacement. Online volunteers would work in shifts to monitor social media sites and extract relevant information to manually create reports. For more information, see 'Libya Crisis Map Deployment 2011 Report' (Standby Task Force 2011) <http://blog.standby taskforce.com/2011/09/01/libya-crisis-map-report/> accessed 20 March 2015. 
a domestic issue around the world. A local demonstration in Casablanca was seen live around the globe, placing it in the international arena.

This new e-revolution generates a sort of symbiosis between the non-violent actors and the media. The live broadcast avoids censorship of information, generating a global and international view of both revolutionary and counter-revolutionary actions. The media benefit from continuous live information, which increases their audiences. This global monitoring encourages the use of non-violent methods, because the international community has more tools to determine who is responsible for the use of violence. It could be said that these news e-tools 'channeled' the Arab Spring revolutions, not only in the sense of distributing information through the channels of the media but also in the sense of shaping the contours of the revolutions themselves. Rather than deriving their sense of themselves as new political actors through revolution violence, as Arendt argued, today's revolutionaries can do so by their almost instantaneous validation by an international community that valorizes the freedom that they seek.

The use of violence and non-violence, both by revolutionary and counter-revolutionary actors, is not only monitored, but also punished and rewarded by the international community. As the case of Libya shows, isolation, economic sanctions, assets and funds freezes, visa bans, the imposition of a no-fly zone, an embargo on arms, ammunition and equipment that could be used for the repression of protesters, and other international measures, are some of the consequences of the use of violence. $^{39}$

Blackberries, tablets, and smartphones made the Arab Spring a twentyfirst century revolution, a new era revolution, shifting ancient domestic phenomena onto the international scene and transforming and updating the ancient theoretical concept of revolution. The Arab Spring seems to be a milestone in the theoretical understanding of revolutions. However, we need to analyze each case to know if the new technologies' deterrence of revolutionary violence - and their magnification of responsive violence - really worked. Consider the following preliminary analysis of the

39 To see the concrete international measures and sanctions that the United Nations imposed on Libya, condemning the violence and use of force against civilians, see UN Security Council Resolution 1970 (26 February 2011) UN Doc S/RES/1970; see also the Council of the European Union, Decision 2011/178/ CFSP of 23 March 2011 amending Council Decision 2011/137/CFSP concerning restrictive measures in view of the situation in Libya [2011] OJ L78/24; and see Exec Order No 13083, 76 FR 11315 (2011) (US), issued by President Barack Obama on 25 February 2011. 
concrete events of the Jasmine Revolution in Tunisia and the Revolution on 25 January in Egypt.

Were the protests violent? In Tunisia popular protests followed the death of four young men within a period of less than fifteen days. On 17 December 2010, the self-immolation of Mohamed Bouazizi; five days later, Houcine Falhi committed suicide by self-electrocuting after climbing an electric pylon; and on 24 December, Mohammad Ammari and Chawki Belhoussine were shot by police in Bouziane. ${ }^{40} \mathrm{~A}$ day later, protests spread across the country, in Kairouan, Sfax, Monastir, Chebba, and other cities. ${ }^{41}$ Police used force to disrupt demonstrations and eventually 219 people died in a month of protests in Tunisia. ${ }^{42}$ On 3 January 2011, a peaceful demonstration in the city of Thala turned violent after the police tried to stop it by firing tear gas canisters at the demonstrators. ${ }^{43}$ The violent repression of protest continued in Thala, when the police fired their weapons after using water cannons to try to disperse a crowd. Moreover, snipers carried out a series of massacres in Kasserine and Thala. On 14 January, the regime imposed a state of emergency, forbidding public demonstrations and limiting other rights and freedoms. The declaration of the state of emergency was the last abuse of Ben Ali's regime and led to violent clashes between protesters and security forces. That same day, Ben Ali reportedly fled to Jeddah in Saudi Arabia.

Describing the Jasmine Revolution as non-violent depends on whether we consider the waves of suicides as violence. Self-slaughter is defined as an act of violence by the World Health Organization, which includes violence against 'oneself' as a violent act, so the initial acts of the Jasmine Revolution might be described as violent - although we are confident that Arendt thought of violence as something directed against

40 Yasmine Ryan, 'Another Tunisian protestor dies' Al Jazeera English (Doha, 31 December 2010) <http://www.aljazeera.com/news/africa/2010/12/ 201012317536678834.html> accessed 13 March 2015.

${ }^{41}$ Al Jazeera English, 'Tunisia jobless protests rage' Al Jazeera English (Doha, 28 December 2010) <http://english.aljazeera.net/video/africa/2010/12/ 20101228182021539319.html> accessed 13 March 2015.

42 BBC, 'Tunisia protests against Ben Ali left 200 dead, says UN' $B B C$ (London, 1 February 2011) <http://www.bbc.co.uk/news/world-africa-12335692> accessed 13 March 2015.

43 Ryan Rifai, 'Timeline: Tunisia's uprising' Al Jazeera English (Doha, 23 January 2011) <http://www.aljazeera.com/indepth/spotlight/tunisia/2011/01/2011 14142223827361.html> accessed 13 March 2015. 
another, not against oneself. After the initial events, the Tunisian revolutionaries' political protests, demonstrations, and strikes flowed in nonviolent channels until the declaration of the state of emergency.

In January 2011 protests in Egypt against government corruption commenced. On 25 January, a national holiday to commemorate the police forces, large numbers of Egyptians took to the streets in several towns across the country. Police and demonstrators collided, and law enforcement officials fired tear gas and used water cannon against demonstrators in Cairo's main Tahrir Square. Protests broke out in the Mediterranean city of Alexandria, the Nile Delta cities of Mansura and Tanta, and the southern cities of Aswan and Assiut. The interior minister said three protesters and a police officer had been killed during the anti-government demonstrations. ${ }^{44}$ Two days later, the Egyptian police and protesters continued to clash throughout the country. Eleven civilians were killed in Suez and 170 injured, and at least 1,030 people were injured countrywide. Immediately the new technologies (Facebook, Twitter, and Blackberry Messenger services) were disrupted. But Al-Jazeera continued recording and broadcasting for the world. ${ }^{45}$

Military troops were ordered onto the streets in Cairo, Suez, and Alexandria but did not interfere in the confrontations between police and protesters. ${ }^{46}$ The following days hundreds of thousands continued to protest and confront the police throughout the country. In Tahrir Square 'the march of millions' stood their ground, despite troops firing into the air in a bid to disperse them. ${ }^{47}$ On 3 February, demonstrations in Alexandria began peacefully, but turned violent. Demonstrations continued on the next days, and on 6 February opposition groups (including the banned Muslim Brotherhood) demanded President Hosni Mubarak's immediate resignation. Three days later, about 6,000 state workers went on strike in Suez. ${ }^{48}$ On 11 February, President Mubarak agreed to step down. After eighteen days of street protests, demonstrations, and strikes

44 Al Jazeera English, 'Timeline: Egypt's revolution' Al Jazeera English (Doha, 14 February 2011) <http://www.aljazeera.com/news/middleeast/2011/01/ $201112515334871490 . h t m l>$ accessed 13 March 2015.

45 Ibid.

46 BBC, 'Egypt's revolution: Interactive map' $B B C$ (London, 11 February 2011) <http://www.bbc.co.uk/news/world-middle-east-12327995> accessed 13 March 2015.

47 Ibid.

48 Los Angeles Times, 'Revolution in Egypt' Los Angeles Times (Los Angeles, 19 June 2012) <http://timelines.latimes.com/egypt/> accessed 13 March 2015 . 
peaceful in origin, the non-violent revolution of 25 January had produced violent confrontations between security forces and protesters with at least 846 people killed and 6,000 injured. ${ }^{49}$

Do these narratives show that the new technologies deterred violence? After the Tunisian experience, Mubarak's government tried to cut off any role for the new technologies in the revolution, but without success. The technologies were disrupted, yet only four days later, Google improved its speak2tweet technology for the people of Egypt. The new technologies clearly were a component of the revolution, at least in the sense that Mubarak understood the risks they posed to his rule.

\subsection{BROADENING THE ARGUMENT}

To move from these narratives to broader points, we must distinguish between 'non-violent actions' and 'actions without violence' ${ }^{50}$ The term 'non-violence' in English encompasses two meanings of the Gandhian philosophy (Ahimsa and Satyagraha), which has given rise to misunderstanding. Ahimsa is a Buddhist and Hindu principle urging avoiding violence. This principle urges people to always be aware that they may hurt some living being, even to the slightest degree, through mind, speech, or action. ${ }^{51}$ This Buddhist ethical precept means 'action based on the refusal to do harm' and it is a basic precept of the second Gandhian concept translated as non-violence Satyagraha. Consequently, for us Ahimsa refers to actions without violence and Satyagraha will be translated as non-violent actions. ${ }^{52}$

For our purposes, a definition of non-violence, such as Ahimsa, that embraces all human actions would make the concept unusable in social and political analysis. For that reason we describe the waves of suicides, political demonstrations, strikes, and massive protests in Tunisia as non-violent actions, not actions without violence.

$49 \mathrm{KCPQ} / \mathrm{Q} 13$ FOX 'Most Memorable News Stories of 2011' $\mathrm{KCPQ/Q13}$ FOX (Seattle, 2011) <http://www.q13fox.com/news/kcpq-most-memorable-newsstories-of-2011-20111-004,0,3268627.photo> accessed 21 March 2012. No longer available.

50 Jacques Semelin and Christian Mellon, La non-violence (Presses Universitaires de France 1994) 13.

51 Leela Gandhi, 'Concerning Violence: The Limits and Circulations of Gandhian Ahisma of Passive Resistance' (1996-1997) 35 Cultural Critique 105.

52 Joan V Bondurant, The Conquest of Violence. The Gandhian Philosophy of Conflict (Princeton University Press 1965) 5. 
The distinction between Ahimsa and Satyagraha can also illuminate the difference between non-violence and pacifism. Non-violence (for us, Satyagraha), unlike pacifism, is motivated with the intent to achieve social or political change. ${ }^{53}$ The Stanford Encyclopedia of Philosophy defines pacifism as 'a commitment to peace and opposition to war [...] [T] oday, [it] includes a variety of commitments on a continuum from an absolute commitment to nonviolence. In contrast to the just war tradition, pacifism rejects war as an acceptable means for obtaining peace [...]'. Pacifism can be used to describe Ahimsa, a commitment to non-violence in one's personal life. ${ }^{54}$ Pacifism, though committed to non-violence, does not necessarily seek political change. Gandhi and Dr. King, though, linked the success of non-violence to its ability to create change. Pacifism as a personal attitude will not be an effective measure in generating this social transformation. ${ }^{55}$

It is impossible for a revolution to avoid 'actions without violence'. Were Arendt's idea of violence to be limited to this alone, her analysis would be consistent with recent experiences. Revolution does imply novelty, irresistibility, and freedom, but also overcoming the regime's physical violence. When revolutionaries are facing the public forces of the regime, they break down physical and structural violence. ${ }^{56} \mathrm{~A}$ revolution must overcome the difficulty of breaking the thought of the regime. Any method that challenges the logic of the sovereign is going to be considered 'violent' by the state, inviting responsive violence whether desired or not by the revolutionaries.

Beyond physical violence, though, there is what we can call symbolic violence. These include strikes, demonstrations, protests, and suicides. They often threaten the state's authority, but also challenge the sovereign's monopolistic use of violence, and for that reason serve as symbolic counters to the state's claim of such a monopoly. And, of course, the state has its own resources of symbolic violence, such as celebrations of the

53 Sharp (n 37).

54 See Andrew Fiala, 'Pacifism' (The Stanford Encyclopedia of Philosophy Summer edn, 2010) <http://plato.stanford.edu/archives/fall2010/entries/pacifism/> accessed 7 August 2012.

55 Ibid.

56 See Pierre Bourdieu, Algeria 1960: The Disenchantment of the World: The Sense of Honour: The Kabyle House or the World Reversed: Essays (Cambridge University Press 1979); Pierre Bourdieu, Language and Symbolic Power (Harvard University Press 1991); Frantz Fanon, Les Damnés de la Terre (La Découverte 2002); George Steinmetz, State/Culture: State-formation After the Cultural Turn (Cornell University Press 1999). 
armed strength of the military. For over thirty years in Egypt, Mubarak was the only one who successfully claimed the monopolistic use of the 'legitimate' physical and symbolical violence. In societies like Ben Ali's Tunisia, Mubarak's Egypt, Gaddafi's Libya, and Mohammed VI's Morocco, symbolic violence was an effective method of exercising power to enable domination. A politically motivated wave of suicides seems to be an extreme violent act against the symbolic violence exercised by the sovereign. This is particularly true in Muslim-majority countries where suicide has negative religious connotations. If the state reacts to these events by implementing more state symbolic violence, or naked violence, the political consequences may be unpredictable.

Here we move away from Arendt's discussion of the emergence of new political actors into self-consciousness, into an older Western tradition, of which Arendt was almost certainly aware. Our aim in what follows is to set up - at some length - a Western tradition to which insights drawn from the Arab Spring can later be brought, in what we hope is a fruitful dialogue.

Symbolic violence's scope is the social Psyche-Polis, the 'public soul' causing that individuals adjust their behavior consciously or unconsciously to an imposed symbolism. As in the tale, Psyche must take a lamp and a knife to cut off the monster's head. The first tool to beat the monster is a lamp, here the strengthening of a critical sense and individual self-determination. ${ }^{57}$ But, she may face Cupid instead. With the enlightenment of the lamp, she will use the knife (revolutionary non-violent methods) if she finds that she is confronting a monster, but if he is Cupid, she will love him forever.

Since Socrates the concept of Psyche (soul or anima) is associated with the Polis. ${ }^{58}$ The political soul is the common element of the ancient Greek citizenry and it allows the ascription of moral and political responsibilities to the individuals as well as isonomy (equality of law). Symbolic and structural violence manipulate this soul, and the first step to stop this annihilation is to illuminate the interference. To do so, citizens, in the Greek sense of the term, need critical and individual self-determination. The resonance with Arendt's argument should be apparent.

Proudhon defines this critical sense as a highly motivated and long debated judgment that requires basically a high degree of impartiality.

57 Lucius Apuleius, 'Cupid and Psyche' in Metamorphoses.

58 See Torsten J Andersson, Polis and Psyche: A Motif in Plato's Republic (Almqvist \& Wiksell 1971). 
The critical sense in Proudhon was the essence of democracy and liberty. Moreover, this kind of judgment must be considered the first political right. This progressive individual self-determination must be based on different elements such as 'the strengthening of critical sense' in democracy. 59

Three initial questions can be formulated about this individual selfdetermination, this ipseity in each member of 'we the people'. The first question is whether citizens today can acquire this degree of critical judgment. Proudhon says Yes, although for him societies need a longterm preparation in citizenship - this preparation must be grounded in equality and freedom. A second question is: What if citizens do not want to assume this critical judgment? This question can be answered with reference to Fromm's idea of an escape from freedom. ${ }^{60}$ Yet, to be uninvolved in political affairs is a right of democracy. The Arab Spring suggests, though, that at least in some places fears of a flight from freedom might be misplaced: the people are not so far removed from political issues.

\subsection{REVOLUTION AND FREEDOM}

When defining violence, Arendt set up a new constitutive feature regarding the concept of revolution: freedom, or more precisely, the search for freedom and liberation as main revolutionary leit-motif. She considered violence as a necessary feature of revolution when it was applied to establish freedom. As we saw, she affirms that the idea of freedom is crucial to any understanding of revolution, and coincident with the experience of a new beginning. ${ }^{61}$

Derrida's discussion of democracy and the relationship between equality and freedom is helpful here. Derrida stated that: 'Freedom is essentially the faculty or power to do as one pleases, to decide, to choose, to determine one-self, to have self-determination, to be master, and first

59 Pierre-Joseph Proudhon, De la critique et des idées dans la démocratie française: à propos d'un ouvrage sur La guerre et la paix (vers 1861) (Manuscrits-documents inedits, ed. Tops/H. Trinquier 1999). On selfdetermination see Jacques Derrida, Rogues: Two Essays on Reason (Stanford University Press 2005); Jacques Derrida, Séminaire La Bête et le Souverain, I, (2001-2002) (Galilée 2008).

60 Erich Fromm, Escape from Freedom (Henry Holt and Company Ltd. 1941).

61 Arendt (n 2) 19. 
of all master of one-self (autos, ipse) ... There is no freedom without ipseity and vice-versa, no ipseity without freedom'.62 This sort of freedom emerged in the eighteenth-century American colonial experience and the French sans coulette insurrection, and, for Derrida, had not been visible since Greek and Roman antiquity. ${ }^{63}$

The Derridian 'ipseity' is what Arendt calls experience of being free. For her, beginning something new was essential to the concept of revolution in the modern age. Doing so was part of the American and French revolutions but also of the Arab awakening. The French revolutionaries felt the experience of the search for freedom, just enough to evoke the revolutionary French national slogan 'Liberté, Egalité et Fraternité'. But Rousseau, Montesquieu, Voltaire, Sieyès, Diderot, Tocqueville, and others not only sought freedom in their revolution, but also defined and updated the concept in their legal and political writings. Doing so, and with their colleagues of the new world, Paine, Madison, Hamilton, Jay, Jefferson, and others, they planted the philosophical, political, and legal seeds to fuel the need for the pursuit of freedom that persists to this day.

Although it would extend this essay unduly to quote from and refer to the extensive work of the French or the U.S. revolutionaries on freedom, as Arendt did, we touch on some of the accounts - because they help us understand the various concepts of revolution in the twenty-first century.

The charter of 1789 collected in a legal-positive document with a 'universal' vocation, the intellectual aspirations of the French revolutionaries. In this sense, article 1's declaration that 'Men are born and remain free and equal in rights', reflects Rousseau's conceptions of freedom as a human right, but also his distinction between natural and civil freedom. By agreeing to a social contract, people relinquish their natural liberty of an unlimited right to everything that tempts them, and in return gain civil liberty, limited by the general will. ${ }^{64}$ It is the second sort of liberty with the acquired moral freedom that makes a person truly free and a master of himself or herself. This conception of liberty, added to the supreme sovereign power that resides in the nation, establishes the ideological roots of the revolution.

Rousseau's focus on freedom and sovereignty also appears in Montesquieu's work, which defines and analyzes the different meanings of liberty. Narrowing Montesquieu's vast work on liberty, he defines liberty

62 Derrida (n 59) 22.

63 Ibid.

64 Jean-Jacques Rousseau, Du contrat social, ou principes du droit politique (first published 1762, Gale ECCO, Print Editions 2010) 10. 
as a right of every citizen (universal) to do whatever the laws permit. Were a citizen to do what the law forbids he would no longer possess liberty, because all his fellow citizens would have the same power. ${ }^{65}$ The definition fits into the concept of Rousseau's civil freedom.

The freedom of every citizen constitutes a part of public liberty. To achieve this degree of political liberty, no person can fear another. Montesquieu continues by stating that countries are not cultivated in proportion to their fertility, but to their liberty. ${ }^{66}$ The ideological significance of the revolutionary doctrine has lasted until today. On 27 October 1946, after the victory of the free peoples over the Nazi barbarity, the French people reaffirmed the Declaration of the Rights of Man and of the Citizen of 1789 as the fundamental principles recognized by the laws of the Republic.

The first character of the modern revolutionary need is this spirit of liberty. But there is another French feature that also appears in modern revolutions, the inclusive concept of national sovereignty that stirred the consciences of the sans coulettes, Girondins, Jacobins, and Montagnards. The theoretical conceptualization of national sovereignty in the French Revolution is attributed mainly to Sieyès and Diderot. ${ }^{67}$ Both define popular and national sovereignty synonymously, and following the logic of Rousseau's social contract, the people-nation ratifies the contract (constituent act) which institutionalizes the state legally.

Then, the people/nation is a pre-constitutive entity, a political body of natural liberty (Rousseau), and after the constitutional agreement creates a state, the people in whom civil liberty resides.

\subsection{REVOLUTION AND SOVEREIGNTY}

The constitutional statement of 'national sovereignty' has its origins in article 3 of the Declaration of the Rights of Man and of the Citizen, 1789, which stated: the principle of all sovereignty resides essentially in

65 Charles-Louis de Secondat, Baron de La Brède et de Montesquieu, Cuvres complètes de Montesquieu: De l'esprit des lois, livre XXXI. Défense de L'esprit des lois (first published 1748, Nabu Press 2010) 172.

$66 \quad$ Ibid 299.

67 Denis Diderot, Ouvres completes (Gallimard 1946); Denis Diderot, Jean Le Rond d'Alembert and Jacques Proust, L'Encyclopédie Diderot et d'Alembert (Eddl /Soldeur, 2001); Emmanuel Sieyès, Qu'est ce que le tiers-état? (Flammarion 2009); Sieyès, Emmanuel Sieyès, Ecrits Politiques (Editions des archives contemporaines, 1985). 
the nation. No individual may exercise authority that does not proceed directly from the nation (or the laws of that nation). In the formulation of national sovereignty, the nation is the holder of sovereignty, it is endowed with 'free will' exercised by its representatives. ${ }^{68}$ This Declaration was a revolutionary achievement - the power now belongs to the nation and not to an individual (king) or group of individuals. The Declaration accommodates Sieyès' and Condorcet's definition of national sovereignty, and also seems to overcome some of the fears and troubles of monarchy, oligarchy, and aristocracy that Montesquieu identified. Two years later, the first article of the Constitution of 1791 codified national sovereignty and stated that sovereignty is indivisible, inalienable, and imprescriptible. Sovereignty belongs to the nation - neither an individual nor any group of people may exercise this sovereignty. Even elected representatives merely exercise the powers associated with sovereignty. ${ }^{69}$

Only two years later, the Jacobin and Revolutionary constitution of 1793 introduced a major change by proclaiming popular rather than national sovereignty. Under this new formulation every citizen owns a piece of sovereignty, with the implication that all national decisions must come from the citizens. If supreme power belongs to a crowd, each member has a portion equal to the rest. Representation survives, though, because no citizen can directly exercise his portion of sovereignty alone, and elected representatives must act on his behalf. ${ }^{70}$

The current French constitution incorporates two antagonistic conceptions. Both theories have always coincided in that French democracy is based on the unity of the people or the nation. Regardless of the debate, the conceptualization of national (first) and popular (late) sovereignty was a great success and embedded in other nations' constitutions it has become a central aim of later revolutions. To achieve national sovereignty, understood not as it is in international law but as it is in French political theory, was undoubtedly one of the goals of the people of the Arab revolutions in Tunisia, Egypt, and Libya.

68 Philippe Ardant, Institutions politiques et droit constitutionnel, libraire générale de droit et de jurisprudence (EJA 2007) 160.

69 Ibid 161.

70 Maurice Duverger, Le système politique français (Presses Universitaires de France 1996) 193. 


\subsection{THE CONCEPT OF REVOLUTION IN FRANCE AND THE UNITED STATES}

The first French constitution, the Charter of 1791, also evidences the revolutionary commitment to freedom. Its Preamble abolished irrevocably the institutions that had been injurious to liberty and equality of rights. The first title codifies liberty in different rights, such as freedom of movement, speech, press, opinion, assembly, and petition. The Declaration of the Rights of Man and of the Citizen of 1789 was included as a Preamble in the constitutions of 1791 and 1793, and then, after more than a century and a half in the constitutions of 1946 and the current constitution of 1958. The universal significance of these events and their persistence over time cannot be explained and understood without analyzing the revolution that happened in those years in the New World. Indeed, the U.S. Founding Fathers first changed the meanings of revolution and constitutions. The relationship between fellow revolutionaries on both sides of the Atlantic is well known, but the influence occurred in the other direction as well: Benjamin Franklin and Thomas Jefferson conducting foreign affairs in Versailles influenced the French revolutionaries.

If the French 'contribution' to the modern revolutionary concept focuses on equality and national sovereignty, the American input is clearly related to the concept of liberty.

Virginia's Declaration of Rights is clear evidence of this statement. Written by George Mason and adopted by the Virginia Convention on 12 June 1776, the Declaration of Rights is one of the first (if not the first) modern 'revolutionary' draft and the starting point of the revolutionary paths in the late eighteenth century. The Virginia Charter set up the origins of the American concept of liberty ('That all men are by nature equally free') that then become universal, but it also stated the revolutionary necessity of freedom ('That all men have inherent rights that nobody can deprive or divest their posterity, namely, the enjoyment of life and liberty'). The Virginia Charter laid down the primary essence of the definition of a modern constitutional state, establishing a comprehensive political order, guaranteeing fundamental rights, and providing for the separation of powers. ${ }^{71}$

The second section of the Virginia Charter is overwhelmingly clear about the establishment of popular sovereignty. Virginia's Declaration, in

71 Ulrich K Preuss, Constitutional Revolution, the Link between Constitutionalism and Progress (Humanity Books 1995) 42. 
turn, deeply influenced the first paragraphs of the Declaration of Independence and also the understanding by the representatives of the thirteen United States, the concept of liberty as an unalienable right.

The Declaration's statement that governments are instituted to secure inalienable rights establishes a fundamental basis for legitimacy in politics and law that clearly transcended the specific time and place of the late eighteenth century America. It became the basis for universal claims around the world. Though some authors have been skeptical of this universal vocation, the theory of American exceptionalism has been overtaken by the triumph of constitutionalism and its values around the world. It is not that only America is a nation conceived in liberty, as Lincoln stated in the Gettysburg Address, but now every nation, through the international regime of human rights and the United Nations system, must rest its claims on liberty and equality - though, as we will see in our case studies, the precise specification of those concepts can vary widely. ${ }^{72}$

The French revolutionaries invoked the universal nature of the American Declaration. Lafayette returned to France after the American Revolution with a copy of the Virginia Charter and asked the National Assembly to approve a Bill of Rights drawing on bills of rights of the American subnational constitutions. Both revolutions claimed to secure human rights and proclaimed universal principles.

But the evidence of Arendt's 'pursuit of freedom' as a modern revolutionary feature appears with the statement that justifies independence itself, the right 'to be free'. This statement shows the American commitment not only to individual but also the collective right to sovereignty in a state dedicated to liberty.

Of course the concepts of freedom and equality established in the United States lost some of their universal transcendence and revolutionary character when they applied only to rich white male citizens,

72 Paul Kahn, Political Theology: Four New Chapters on the Concept of Sovereignty (Columbia University Press 2011). See Antoni Abat i Ninet, Constitutional Violence, Democracy, Legitimacy and Human Rights (Edinburgh University Press 2012).

For a critical perspective on American exceptionalism and human rights system see Michael Ignatieff, American Exceptionalism and Human Rights (Princeton University Press 2005). The author recognizes the role of the United States in the promotion of global human rights, and places American exceptionalism in the signature of international treaties, in the use of different standards to judge United States' and other countries' conducts and actions, and the practice of originalism by U.S. courts. 
excluding more than half of the population - the problem we referred to earlier as that of historical contingency. If the telos of the American revolution was to obtain rights to some determinate people, the relative lack of overt and violent conflict within the new United States rendered unnecessary the universal revolutionary myth. Later social movements in the United States emphasized the effects of inequality sustained without overt violence. Arendt's formulation offers a pointed contrast: 'the transformation of the Rights of Man into rights of Sans-Culottes was the turning point not only of the French Revolution but all revolutions that were to follow' ${ }^{73}$

\subsection{REVOLUTIONS AND THE ARAB SPRING}

Our argument so far raises the question, are the (universal) rights claimed by the revolutionaries in Tahrir or Tunisia after the triumph of the Arab Spring biased toward a concrete social class or statement, a particular religion or ethnic group, or on the contrary, have these rights been acquired by the people? It seems impossible to answer this question now, because we need time to consolidate and stabilize the post-revolutionary scenario, but the constituent process (its actors, decision-making bodies), the new constitutional charters, and the first democratic elections ever in these countries, all may provide some clues.

Although it seems impossible to avoid the substitution of a ruling class (pre-revolutionary) by another (post-revolutionary), as happened in the U.S. and French eighteenth-century revolutions, the communist revolutions, or even in the color revolutions, the point is not only that this new post-revolutionary ruling class has reached authority legitimately, democratically, and respecting human rights, but also that its exercise of power also meets these requirements. The post-revolutionary rights are also rights of those who lost, of those who opposed the revolution, of the non-actors. Liberal and democratic transition requires the generosity of the victor.

These original features of the modern notion of revolution that can be appreciated in the American and the French experiences and they have been reproduced in the Arab Spring phenomena. The need for liberty, both individual and collective, the awareness and trust in achieving a political change are characteristics that have driven the revolutions in Tunisia, Egypt, and Libya. Again, this is not to say that those revolutions

\footnotetext{
73 Arendt (n 2) 51.
} 
have, or inevitably will, produce liberal constitutions, but rather that liberal themes are now an inextricable component of post-revolutionary efforts to create new constitutions.

Arendt's notion of revolution also includes novelty and a new beginning. Only where change occurs as a new beginning can we speak of revolution. ${ }^{74}$ From this point of view it appears that the constitutional amendment of Morocco can be described as a successful reform effort, because it produced important liberal constitutional advances, but not a revolution because it did not occur in the form of a sharp break from the prior regime.

The Moroccan awakening does not meet the requirement of irresistibility, understanding this term as implying no possibility of turning back to the pre-revolutionary stage. In contrast, such 'irresistibility' probably triggered war in Libya and Syria. If according to Arendt, in any understanding of 'modern' revolution the idea of (public) freedom and the experience of a new beginning should coincide, in Morocco there has been no such concurrence. But, as we observed in the Introduction, we think it important to wonder why it matters that we call this effort a 'mere' reform rather than a revolution.

\subsection{ARAB SPRING REVOLUTIONS - THE CONCEPT}

This section examines the locution 'Arab Spring' or 'Arab Awakening', paying special attention to the terms' vagueness and inaccuracy so as to allow us to analyze the causes of, and prospects for, the Arab Spring. This section supplements the definition of revolution applied to the Arab Spring by introducing a substantive democratic standard.

The label 'Arab Spring' or 'Arab Awakening' covers the massive mobilizations, strikes, and upheavals that occurred in the Middle East and North African countries from December 2010 to early 2011. But the label 'Arab Spring' also embraces various realities, countries with particular political, economic, and social idiosyncrasies, with their own constitutional and political identities. It is necessary to take account of these different realities embraced under the notion 'Arab' to understand the phenomena, motivations, claims, expectations, reactions, and counterreactions of the Arab Spring.

Relatedly, we must take account of the huge social and economic differences, and the immense inequality between the elites and the rest of

74 Arendt (n 2) 25. 
the population within the revolutionary process. This disparity, the desperation, and the lack of expectations and hopes of a large part of the population are some of the factors that fed the revolution.

The vagueness and variety of phenomena contained in the locution 'Arab Spring' can be narrowed temporally, geographically, and materially.

Temporal limitations. It seems generally accepted that the Arab Spring began on 17 December 2010, with the self-immolation of Mohamed Bouazizi in Tunisia. As noted earlier, the protests spread across Tunisia and forced the resignation of President Ben Ali, in office since 1987. As Dabashi points out, this first unexpected but successful seesaw of massive popular protest and public denunciation in Tunisia became a familiar pattern throughout the Arab world..$^{75}$

The successful result of the first experience produced a domino effect, a bigger Spring. The protests in Egypt began three days after Ben Ali's resignation. We cannot know, of course, what would have happened if the protest in Tunisia had failed or ended with a reformist solution. In the event, the 'awakening' continued to spread out in the region before anyone knew the final result of the revolution in Egypt. Certainly, the final result of the Jasmine Revolution was enough to encourage populations elsewhere to claim their political and economic rights.

Another element that fueled the expansion of the political demonstrations was the reaction of the governments. Mubarak's action in sending in armed gangs on camels to attack demonstrators and the assassination of hundreds of protestors in Benghazi had counterproductive effects for the regimes. Protesters became more determined in Bahrain, Syria, Yemen, and elsewhere.

Geographical limitations. The Arab Spring as a phenomenon refers to revolutions, revolts, uprisings, massive demonstrations, and wars, located in Middle Eastern and North African nations with Muslim majorities. All these phenomena have led to the most extreme reordering of political structures in the region since national independence. ${ }^{76}$ This new political ordering is clearly related to constitutions and constitutional meanings. Even if Islamic constitutionalism is considered exceptional, the new political restructuring has shown the strength of constitutionalism in

75 Hamid Dabashi, The Arab Spring: The End of Postcolonialism (Zed Books 2012) 17.

76 George Joffé, 'Introduction' (2011) 16 The Journal of North African Studies 506. 
Islamic countries. The immediate post-revolutionary processes in Tunisia and Egypt, and immediate post-civil war scenario in Libya are embodied in new constituent processes and new constitutions. These new procedures opened to new political actors after democratic elections, and some of the new constitutions will juridify a new political reality. In Morocco, the constitutional amendment has been an evident political tool to reform the state but at the same time, to tame the popular upheaval. The new elites, as elsewhere, have used constitutional texts to consolidate and legitimate legally political transitions to a more democratic regime.

Material limitations. Ramadan highlights some of the commonalities of these events focused against social and economic conditions, the rejection of dictatorships, and to fight against corruption. ${ }^{77}$ Democratic reform must be included in this shared aim. Having been caught off-guard by these events, researchers on the region have now been forced to rationalize the unexpected emergence of decentered politics and pro-democracy movements across the Arab world. ${ }^{78}$ To establish the temporary end of this phenomena is more complicated. But as Joffé states: 'Early ideas of a domino effect have now been set aside, for it is clear that some attempts to transform regimes through peaceful mass demonstration have ended in tragedy, whilst others have been adroitly managed by the regimes they challenged'. ${ }^{79}$

The 'Arab Spring' is a popular phenomenon that includes social, political, economic, and democratic claims, and not only the way that these claims were channeled (revolutions, uprisings, or massive demonstrations). Assuming that each case is specific and that the claims were essentially domestic, the content and goals aimed were similar and expressed in Arab countries. As we have argued, another feature of the Arab Spring is the non-violent nature of the original challenges throughout the region. The fact that the regimes reacted violently to these challenges does not change the peaceful nature of the phenomenon in these countries too. Another factor to be considered by the theorists of revolutions of the absence of violence can be that modern revolutions must be non-violent - as opposed to the historic revolutions of America and France - because of the weaponry and military sophistication of armies today.

77 Tariq Ramadan, The Arab Awakening: Islam and the new Middle East (Penguin Books 2012) 2.

78 Timo Behr, 'Talking about the Revolution: Narratives on the Origin and Future of the Arab Spring' (9 Papers IEMed 2012) 7.

79 Joffé (n 76) 505-6. 
We now highlight phenomena that were common in the different scenarios, to justify conceptually the label 'Arab Spring'.

\subsection{GEOPOLITICAL DIMENSIONS OF THE ARAB SPRING}

The first generic element is that all the countries affected by this social, political, and economic movement were 'Green Revolutions'. The people in the Middle East and North Africa have the same needs as people elsewhere, and they also have a claim for democratization, social justice, and better life expectations. But the term Arab in the revolutionary context has additional connotations. Have these revolutions aimed at securing freedom, equality, justice, and democracy? Or have they been grounded in the pursuit of religious goals that exclude them? The use of the term Arab allows us to raise the latter question, by opening up the possibility that the 'Arab Spring' events were rooted not exclusively in 'Islamic' concepts but were strongly influenced by more local concerns. ${ }^{80}$ Ben Jelloun remarks that in the protests and revolts, there were no slogans against the United States, Europeans, or Israel, as characterized in earlier street protests. This time, Arabs linked their destiny to modernity without blaming the rest of the world. ${ }^{81}$

The answer is crucial to understanding the reasons that led to the revolution and its transnational expansion. We identify two stages of the political revolution. The first phase arises from the pre-revolutionary reasons, arguments, and objectives that generated the initial revolutionary acts. In this first stage, no religious claims (or anti-Israel slogans) were prominently featured. The leit-motif of the revolution was domestic and secular. The revolutionaries claimed against the domestic dictatorial regimes that were ruling their country. But, in a second stage, once the revolution triumphed, religious political parties and agents started to add non-secular grounds to the post-revolutionary scenario.

Egypt provides a good example of this evolution. The revolutionaries in Tahrir and Alexandria, or at least the vast majority of them, did not demand the foundation of a religious state or make other religious

80 We suspect that the term 'Arab Spring' took hold because it is more euphonious than 'Islamic Spring', but we do not discount the possibility that racialist thinking - as contrasted with religion-oriented thinking - affected the choice of terminology.

81 Tahar Ben Jelloun, L'etincelle. Révoltes dans les pays arabes (Gallimard 2011) 13 . 
demands. After the first free elections, though, the political branch of the Muslim Brotherhood was victorious. The Salafis also obtained important roles. The split between Sunnis and Shiites, important in some nations, is a factor to be considered in analyzing the path of the revolutions, revolts, and civil wars in the Arab countries. The religious, social, but also political confrontation between these two branches of Islam has encouraged and fueled, in specific cases, revolts against the regime at hand. The division between Sunnis and Shiites sometimes allowed the more or less direct intervention of third countries in domestic scenarios.

Popular convulsion and democratic claims have been used by the leading regional powers to extend their geopolitical power. Taking advantage of the Arab Spring to gain better positions on the new Islamic geopolitical board is not only attributable to the 'classic' leading Sunni and Shiite powers, but also to new actors (such as Qatar and Bahrain) on the scene. This foreign interference in funding or impeding the revolution is also a fact to be analyzed in order to understand the revolutionary path and all its players. We cannot elide this factor under a general concept, such as 'Arab'.

Geostrategic competition is fueled mainly by Saudi Arabia, a selfproclaimed protector of Sunni Islam, and Iran, self-declared as a protector of Shia Islam. These two protagonists are involved in a sort of new cold war. ${ }^{82}$ The rivalry also interferes with U.S., EU, and Israeli international relations with the nations of the Middle East and North Africa. After the revolution of 1979 the United States broke with Iran and cultivated closer relations with the leaders of Sunni Arab states such as Egypt. This affiliation became more complex after the September 11 attacks. Al Qaeda is generally Sunni, and many of its operatives come from extremist religious circles inside Saudi Arabia. ${ }^{83}$

Independent of, but related to its response to the Arab Spring, the Saudi strategy to consolidate and expand its influence in the Arab world came through the Cooperation Council for the Arab States of the Gulf

82 See Patrick Seale, The Struggle for Syria (Yale University Press 1987); Malcolm Kerr, The Arab Cold War (Oxford University Press 1971); Mohammed Ayoob, 'The Arab Spring: Its Geostrategic Significance' (2012) 19 Middle East Policy 84; Curtis Ryan, 'The New Arab Cold War and the Struggle for Syria' (2014) 262 Middle East Report <http://www.merip.org/mer/mer262/new-arabcold-war-struggle-syria> accessed 17 March 2015.

83 Seymour M Hersh, 'The redirection, is the Administration's new policy benefiting our enemies in the war on terrorism?' The New Yorker (New York, 5 March 2007) < http://www.newyorker.com/magazine/2007/03/05/the-redirection> accessed 17 March 2015. 
(GCC). This international board created in 1981 aims at coordination, cooperation, and integration among the United Arab Emirates, the State of Bahrain, the Kingdom of Saudi Arabia, the Sultanate of Oman, the State of Qatar, and the State of Kuwait. ${ }^{84}$ In the Arab Spring, the Saudi Kingdom sought to reaffirm its leadership within the GCC by opening its doors to Morocco and Jordan, two Sunni monarchies and the only Arab kingdoms not in the GCC. From this position, reinforced by the Council, Saudi Arabia led a sort of counter-revolution trying to weaken the Arab Spring effects. ${ }^{85}$ This counter-revolutionary effort of the rulers of these conservative monarchies has been two-fold: internally, through a combination of heightened repression and affirmative economic incentives; and regionally, consolidating alliances Saudi Arabia sought so as to contain the revolution in Egypt. Among the actions to fulfill this goal, we include King Abdullah's threat to countersign President Mubarak's administration if the United States withdrew its support from its ally. ${ }^{86}$ Once the revolution triumphed, though, the Kingdom renewed its geopolitical strategy, extending $\$ 4$ billion to Egypt to shore up the post-Mubarak state to ensure its influence and prominence. ${ }^{87}$

Saudi Arabia also has included Morocco and Jordan in its geopolitical strategy. (Morocco was invited to join the union with a five-year economic development plan. $)^{88}$ In doing so, the Saudi Kingdom not only reinforced its position in the GCC, but also consolidated the Council as an alternative to the Arab League. The challenge to Arab League predominance was conducted through a new reading of the claim of Arab unity led now by the GCC. As Kamrava affirms: 'The stress of the Arab Spring has reignited the need for unity, this time under the auspices not of the fractious and divided Arab League, but under the rubric of the GCC. Within the GCC, Saudi Arabia's counter-revolutionary leadership

84 See Cooperation Council for the Arab States of the Gulf, 'The Charter' (The Cooperation Council for the Arab States of the Gulf) <http://www.gccsg.org/eng/indexfc7a.html?action=Sec-Show\&ID=1> accessed 17 March 2015.

85 Mehran Kamrava, 'The Arab Spring and the Saudi-Led Counterrevolution' (Elsevier Limited on behalf of Foreign Policy Research Institute 2012) $96<$ http://www18.georgetown.edu/data/people/mk556/publication-61403. pdf $>$ accessed 17 March 2015.

86 Ibid 98.

87 Ibid 103.

88 See PressTV, 'Jordan, Morocco to join [P]GCC' PressTV (Tehran 11 May 2011) <http://www.presstv.ir/detail/179363.html> accessed 9 October 2011. No longer available. 
has enhanced its role and is slowly pushing it into the position of prominence that it assumes it rightly deserves'. ${ }^{89}$

It is not clear if this economic and political influence has been a decisive factor in stopping the Arab Spring, but it is a matter of fact that the Arab monarchies have remained in power. The key point is to note the possible Saudi influences to counterbalance the revolution in Egypt and Morocco.

On the opposite side and also playing a special role is Iran. The Islamic Republic of Iran is the major opponent of Sunni power in this new cold war. Iran has also played its trump card in the Arab world. The 'awakening' put, in some sense, its geopolitical influence and Shiite domination at stake. The tension between the two blocs was evident when Saudi Arabia and Bahrain denounced Iran as the primary culprit in Bahrain's problems. ${ }^{90}$ Narrowing the Iranian activity to the cases examined in this essay, we start with Egypt. Egypt's leaders have long been suspicious of the connection between the Muslim Brotherhood and Iran, based in large part on Iran's long-standing ties with Hamas - an offshoot of the Brotherhood. ${ }^{91}$ These ties date back to pre-revolutionary Iran. The Muslim Brotherhood has had a major impact on Islamic revivalism in Iran, a movement that sought to promote Islam not just as a religion but as a political and governmental ideology. ${ }^{92}$

The Muslim Brotherhood was born in Egypt in 1928 after the collapse of the Ottoman Empire. Its ideology can be summarized in two points: the renaissance of Islam; and fighting against colonialism and Western influence. ${ }^{93}$ The Muslim Brotherhood became politically active against Nasser's popular socialism. In 1954 the Egyptian government accused the Brotherhood of the failed assassination attempt on Nasser, and soon afterwards the organization was abolished and legally banned.

With the execution in 1966 of Sayed Qutb, one of the most important thinkers of this movement, the Brotherhood continued to develop in Egypt and abroad with the creation of political parties and associations

89 Kamrava (n 85) 101.

90 Kamrava (n 85) 99.

91 Mehdi Khalaji, 'Egypt Muslim Brotherhood and Iran’ (Policywatch 1476, The Washington Institute for Near East Policy 2009) <http://www.washington institute.org/policy-analysis/view/egypts-muslim-brotherhood-and-iran> accessed 17 March 2015.

92 Ibid.

93 Tahar Ben Jelloun (n 81). 
elsewhere, such as Hamas in Gaza. ${ }^{94}$ The Egyptian branch of the Muslim Brotherhood cautiously welcomed the Ayatollah Khomeini, which may have given the Brotherhood the confidence to attack Mubarak's secular regime. ${ }^{95}$ Domestically the Brotherhood was not recognized as a political party, but Anwar Sadat, Nasser's successor, tolerated it. ${ }^{96}$ In the Mubarak regime, the legal status did not change, but the Brotherhood's political influence gradually increased.

On 6 February 2011, Omar Mahmoud Suleiman, the Egyptian vicepresident, appointed during the demonstrations, received a delegation from the Muslim Brotherhood and negotiated the country's political transition with it. ${ }^{97}$ This meeting shows the real political weight of the Muslim Brotherhood in pre-revolutionary Egypt. This political position was confirmed in the first democratic elections, but also shows that the Islamic movement played a role in the revolution. The democratic involvement and participation of the Muslim Brotherhood was initiated in the Parliamentary elections in 2005, when the candidates appeared as independents. ${ }^{98}$ In 2010, though the first revolutionary initiative and main public prominence probably did not belong to the Islamic movement, the Brotherhood certainly took advantage of the winds of change.

The fall of Hosni Mubarak presented a dilemma for the international community, democracy vs. stability. The United States, the European Union, and Israel lost an ally that brought stability in the region, and the vacancy was understood as a good opportunity for Tehran to keep threatening Israel. ${ }^{99}$ The Muslim Brotherhood was the best device for Iran to use in promoting its role as a regional power because of the Brotherhood's deep political roots, its national stature, and the results of the first democratic elections. But the Islamic association was not the 2003).

94 Graham E Fuller, The Future of Political Islam (Palgrave MacMillan

95 Khalaji (n 91).

96 Brynjar Lia and Jamal al Banna, The Society of the Muslim Brothers in Egypt: The Rise of an Islamic Mass Movement 1928-1942 (Gartner and Ithaca Press 2006).

97 Christiane Amanpour, interview with Omar Soleiman (ABC 6 February 2001) <http://www.youtube.com/watch?v=ZIOHoZCzDlg> accessed 17 March 2015.

98 John R Bradley, Inside Egypt: The Land of the Pharaohs on the Brink of a Revolution (Palgrave MacMillan 2008).

99 Peter Goodspeed, 'As Arab Spring Topples Dictators, Iran Influence Grows' National Post (Toronto, 26 November 2011) <http://fullcomment. nationalpost.com/2011/11/26/peter-goodspeed-the-arab-Spring-has-allowed-iranto-expand-its-sphere-of-influence/> accessed 17 March 2015. 
only way Iran could deal with the new reality. It also used Hamas and other terrorist groups to achieve the target.

Some considered the rivalry between Sunni and Shiite as a pure inter-Arab conflict over dividing power, rather than an ideological rivalry, in part because achieving an ideology-dominated Shiite crescent is likely to be quite difficult, if not impossible. ${ }^{100}$ On this view, Iran's attempt to create a coalition of Shiite-friendly governments is based on a strategic rationale, grounded in pragmatism rather than ideology. ${ }^{101}$

The Arab Spring has also allowed new agents to participate internationally. For example, Qatar and Bahrain have been leading supporters of the protest movements in the Middle East and North Africa. The wealthy Gulf emirate of Qatar has been trying to convince the West since the 1990s that it could be a valuable mediator in the numerous conflicts of the region. The close ties that the Emirate has with the most important actors of the region (Iran, Syria, Hezbollah, and Hamas) but also with Israel, place it ideally to develop this role. In this sense, Qatar has understood the Arab Spring as an excellent opportunity to make evident its role of mediator, and urged the Arab League to support the NATO intervention in Libya and took the lead imposing sanctions against the regime of Bashar al-Assad in Syria. ${ }^{102}$ The Syrian opposition used Doha as a place to formalize a unified umbrella organization to become a credible alternative to the Damascus government. ${ }^{103}$

When the Arab Spring began, Qatar started supporting protest movements, in particular the Islamist forces connected to the Muslim Brotherhood. ${ }^{104}$ This seems to corroborate the existence of an unpublicized task of the Islamic movement in the revolution. Of course, the Gulf monarchy is not aligned with the claims of democracy, justice, and dignity that the

100 Kayhan Barzegar, 'Iran and The Shiite Crescent: Myths and Realities' (2008) XV (I) Brown Journal of World Affairs 87.

101 Ibid.

102 Guido Steinberg, 'Qatar and the Arab Spring, Support for Islamist and New Anti-Syrian Policy' (SWP Comments 7, February 2012, Stiftung Wissenschaft und Politik 2012) <http://www.swp-berlin.org/fileadmin/contents/products/ comments/2012C07_sbg.pdf> accessed 17 March 2015. On the role of Qatar as a mediator see the Doha Agreement, signed on 21 May 2008 by the Lebanese factions agreeing the national unity, and also the Doha Agreement signed on Monday 6 February 2012, by Hamas and Fatah intended to achieve the formation of a Palestinian unity government headed by Mahmoud Abbas.

103 See Neil MacFarquhar, 'Syrian Opposition Meets to Seek Unity' New York Times (New York, 8 November 2012) <http://www.nytimes.com/2012/11/ 09/world/middleeast/syria-war-developments.html> accessed 17 March 2015.

104 Steinberg (n 102) 3. 
Arab Spring put forth. The Qatari elite differentiate between the nation's area of influence and the Persian Gulf. Consequently, petrodollars from Doha did not fuel the winds of change and protests in Oman, Saudi Arabia, Kuwait, and Bahrain, but supported the Islamists in Tunisia, Egypt, and Libya. Qatar was the first Arab country to recognize Libya's National Transitional Council based in Benghazi and took a leading role by urging the Arab League to impose a no-fly zone and to call for the military intervention in Libya. ${ }^{105}$ But when the mass protests came into the neighboring Kingdom of Bahrain, Qatar supported the decision of the GCC to intervene and have the military stop the revolt. ${ }^{106}$

The involvement of foreign powers in the domestic path of the Arab Spring in Tunisia, Egypt, Morocco, and Libya, modified the original messages of the revolution to advance their geopolitical aims. Beyond geopolitics, though, other large causes led to the fall of regimes during the Arab Spring.

\subsection{DOMESTIC ROOTS}

These causes are common in the four scenarios analyzed, and they show that Arab societies are not dramatically far removed from Western societies with regard to their political needs, concerns, and future prospects. While it is difficult to cover all the causes that led to the Arab Spring in the four different cases, we can place some of the common claims in three key categories: economic, political, and social. Political, social, and economic reform must occur essentially simultaneously, because the protests' causes were interwoven.

Economic reasons. The protests were motivated not just by demands for greater political freedom but also by popular frustration and economic inactivity. The economic motivation of the revolution is evident: poverty, unemployment, and lack of economic opportunities. The economic struggle was obvious in the demonstration on 21 January 2011 in Amman (Jordan), when more than 5,000 people protested against the price of fuel

105 Ibid 4.

106 On the intervention of the GCC in the Arab Spring see Silvia Colombo, 'The GCC Countries and the Arab Spring. Between Outreach, Patronage and Repression' (Working Paper, Istituto Affari Internazionali 12/09/2012) <http:// www.iai.it/sites/default/files/iaiwp1209.pdf > accessed 17 March 2015; Kamrava (n 85). 
and increased taxation. Nor were protests motivated by economic concerns unique to Amman, as we have seen economic unrest brewing in Palestine.

The acts that instigated the revolts in the Middle East and North Africa resulted mainly from economic strangulation and the lack of opportunities in prospect. During the period 1996-2006, the labor force witnessed unprecedented growth, three times as much annually as the rest of the developing world, resulting in one of the largest rates of youth unemployment in the world.107 The key economic problem is that there are few jobs to go round for young people, and many of these young people are not only unemployed, they are also unemployable. This is clearly a failing of both the education system and the economic structure. ${ }^{108}$ This system has resulted in high rates of unemployment and underemployment. According to the International Labor Office, the socioeconomic profile of the region is characterized by high rates of unemployment, underemployment, informal employment, and low productivity. ${ }^{109}$

The cases of Mohamed Bouazizi and Houcine Falhi, young people without hope to continue supporting their families, and with no possibility of being listened to by the local bureaucracy, were not the exception but the 'normal' rule for a big majority of Tunisians, Egyptians, Moroccans, and Libyans. Bouazazi, a young itinerant trader in fruits and vegetables in Sidi Bouzid, suffered extreme humiliation by the police officers who confiscated his goods and condemned him to misery and desperation. Houcine Falhi cries out, 'No to misery, no to unemployment!' before electrocuting himself. ${ }^{110}$

It seems generally accepted that the main revolutionary discourse was created by a new generation that returned from abroad, bringing with

107 Adeel Malik and Basseem Awadallah, 'The economics of the Arab Spring' (OXCarre Research Paper 79, Oxford Centre for the Analysis of Resource Rich Economies 2011) 2 <http://www.oxcarre.ox.ac.uk/files/ OxCarreRP201179.pdf> accessed 17 March 2015.

108 Adeel Malik, 'The economics of the Arab Spring' Al Jazeera English (Doha, 13 October 2011) <http://www.aljazeera.com/indepth/opinion/2011/10/ 20111010142425419849.html> accessed 17 March 2015.

109 International Labor Office, 'Overview of the Regional Office for the Arab States' (International Labor Office, January 2011) <http://www.ilo.org/ public/english/region/arpro/beirut/downloads/publ/overview_eng.pdf> accessed 17 October 2012. No longer available.

110 See Darryl Thomas, 'Rebellion or Refusal' (Process: 2015, 25 January 2011) <https://darrylthomas.wordpress.com/2011/01/25/rebellion-or-refusal/> accessed 17 March 2015. 
them a new discourse aiming at the democratic and economic regeneration of their countries. But, the breadth of the protests shows that this generation was not alone. The economic situation of millions of people was truly dire.

Not merely as a symbol, food played a large role in the upheavals. Bahrain, Yemen, Jordan, Egypt, and Morocco saw demonstrations about food in 2008, and all experienced political uprisings three years later. The Arab Spring was obviously about much more than food, but this first necessity played a basic role. 'The food-price spike was the final nail in the coffin for regimes that were failing to deliver on their side of the social contract'. ${ }^{111}$ Along with high rates of inflation, this consigned the working class to a world in which corruption was the only path to survival. At the same time, it showed that 'Arab socialism' was unable to accomplish its very first goal, to stop famine and to reduce social inequalities.

Today the economic depression in the post-revolutionary countries manifests itself in four areas: 1) instability that has driven away customers and undermined business confidence; 2) strikes, as workers now feel able at least to vent their frustration after years during which they feared repression; 3) government machinery that functions badly if at all; and finally, 4) the chill that has descended over all businesses connected to the previous rulers, piling on yet more uncertainty. ${ }^{112}$ Is the revolution going to improve the economic situation? At the moment the answer seems to be negative. However, we need time to properly answer this question, by observing if the people can express their concerns and needs by provoking systemic changes.

\subsubsection{Social Motivations}

Here we focus on the lack of social justice and the exclusion of social minorities. All these elements, present in the pre-revolutionary Arab societies, can be considered, among others, the main cause of a social failure.

The unfolding crisis has as a singular failure the unsuccessful development of a strong private sector. While a centralized bureaucratic system

111 The Economist, 'Food and the Arab Spring: Let them eat baklava' The Economist (London, 17 March 2012) <http://www.economist.com/node/ 21550328> accessed 17 March 2015.

112 The Economist, 'Arab Spring economics. An unfinished business' The Economist (London, 4 February 2012) <http://www.economist.com/node/ 21546018> accessed 17 March 2015, see also Malik and Awadallah (n 107). 
worked well for ruling elites and the narrow clienteles that thrive with their support, it failed to deliver prosperity and social justice to ordinary citizens. ${ }^{113}$ This fact increased inequality, pressing down the incomes of middle-class and working families. The differences between rich and poor grew and social tension increased.

The economic and political grievances were intrinsically interlinked, and the growing social fissure was reflected in daily life. The same system collaborated in the alienation and despair of the lower classes. The case of Mohamed Bouazizi also symbolized unfair discrimination, the lack of social justice, and the most elementary human rights, such as freedom of speech. His dignity as a citizen and as a human being was completely denied. The regime quashed the dignity of a complete sector of the society. Arendt's observation that the peasantry in prerevolutionary France were subjects of the king, not citizens, is applicable, appropriately modified, to the pre-Arab Spring Middle East and North Africa.

The acts of public officers in Tunisia were not the exception, but again the general rule of a dehumanizing regime, a normal way to act according to the premises of a regime that considered the vast majority of the citizens as outlaws. In Tunisia, the regime had a hard core of repressive legislation to stifle any sort of possible social opposition.

Another factor to take into consideration was the impunity with which the regime's police repressed, tortured, and murdered. This fact is common to many dictatorial regimes, especially the particularly alarming regimes in Egypt and Libya. In the case of Mubarak, human rights offenses included torture, curtailing of freedom of speech, and mass arrest of street children. ${ }^{114}$ Socially speaking, the revolution was a consequence of the clientelism of the ruling regime, a repressive and corrupt way of perpetuating and deepening a social abysm. Social grievances pushed the protests into attempts to create a new political order.

113 Malik and Awadallah (n 107) 4.

114 See Editorial, 'When will the crime of torture stop?' (Egyptian Organization of Human Rights 2009) <http://en.eohr.org/2009/03/11/when-will-thecrime-of-torture-stop/> accessed 17 March 2015. On offenses related to torture see Amany Radwan, 'Egypt's Torture Video Sparks Outrage' Time (New York City, 23 January 2007) <http://www.time.com/time/world/article/0,8599,158 1608,00.htm> accessed 17 March 2015. 


\subsubsection{Political Motivations}

The political reasons for the revolution are also clear. The catalogue of political grievances was enormous. Some of the reasons have been previously identified, but it is necessary to highlight the endemic and massive corruption in all the public functions and sectors. Corruption also consolidated in the mutual dependence between the ruling regimes and the economic elites, increasing not only the social chasm but also the sense of bad governance.

In the case of Egypt, corruption at both grand and petty level had become increasingly noticeable in the last decade of Mubarak's rule. The perception of corruption among Egyptians went beyond the daily reality of bribery and the awareness of fraudulent business dealings to a more generalized sense that rewards were unfair. ${ }^{115}$ Mubarak's family worth was up to $\$ 70$ billion due to corruption, and knowledge of that fact increased the public's sense that corruption occurred with impunity. ${ }^{116}$

Mubarak's government launched a number of measures to stop corruption, such as the creation of the National Committee to Combat Corruption and the Transparency and Integrity Committee. However, it was a widely-held perception that Mubarak controlled all existing anticorruption initiatives and agencies, and that these agencies also served his personal political agenda. This explained why corruption scandals involving the sale of public companies at under-valued prices to Mubarak's affiliates had few consequences for the parties involved. ${ }^{117}$

Furthermore, it seems that in cases where action had been taken against high-ranking officials involved in corruption, those officials in question had already fallen out of the government's favor. ${ }^{118}$ Accountability of the government and Parliament was generally weak, while regulations to govern conflict of interest and asset disclosure for members of government and the head of state were largely ineffective. ${ }^{119}$

115 Jane Kinninmont, 'Bread, Dignity and Social Justice. The Political Economy of Egypt's Transition' (Briefing Paper, Chatham House 2012), 5 $<$ http://www.chathamhouse.org/sites/default/files/public/Research/Middle\%20East/ bp0412_kinninmont.pdf> accessed 17 March 2015.

116 Philip Inman, 'Mubarak family fortune could reach $\$ 70 \mathrm{bn}$, says expert' The Guardian (London, 4 February 2011) < http://www.guardian.co.uk/world/ 2011/feb/04/hosni-mubarak-family-fortune> accessed 17 March 2015.

117 Andrew Puddenpath, 'Corruption in Egypt' (Global Partners and Associates 2012) <http://global-partners.co.uk/wp-content/uploads/Corruption-in-EgyptReport.pdf $>$ accessed 23 October 2012. No longer available.

118 Ibid.

119 Ibid. 
But Egypt was not the exception. In the other three nations we review we find systemic corruption, with a significant percentage of the economic resources of the domestic economy devoted to corruption. The small elites linked to the regime were direct beneficiaries of that portion of the country's economic resources.

In addition to these economic privileges, these groups enjoyed legal and political impunity. ${ }^{120}$ This endemic corruption was even more serious in a situation of deep economic crisis and lack of opportunities for the young. Corruption was also related to other political demands of the revolution such as the necessity for political inclusion, the recognition of freedom of expression, opinion, association, press, publication, and assembly, but also the recognition of political pluralism.

All these political rights were incorporated in the constitutional texts and the international treaty obligations recognized by Tunisia, Egypt, Libya, and Morocco. But there was no real enforcement and effectiveness of these rights. ${ }^{121}$ For example, in Egypt political dissent was suppressed, political demonstrations dispersed, and journalists, bloggers, and Muslim Brotherhood members detained. Security officers used lethal force against migrants attempting to cross into Israel and arbitrarily detained recognized refugees. ${ }^{122}$

In Tunisia, during Ben Ali's first year in power thousands of political prisoners were amnestied. He also abolished the state security court and the presidency for life, reformed laws governing pre-trial detention and ratified the United Nations convention on torture. ${ }^{123}$ But the regime changed. As in other Arab countries such as Libya, most Tunisians tolerated the government's repression as necessary to obtain a vigorous economy that could generate new jobs. After an economic crisis in 1992,

120 See John Waterbury, 'Corruption, Political Stability and Development: Comparative Evidence from Egypt and Morocco' (1976) 11 Government and Opposition 426; Daniel Treissman, 'The Causes of Corruption: a Cross-National Study' (2000) 76 Journal of Public Economics 399; Giovanni Sartori, 'Comparing and Miscomparing" (1996) Journal of Theoretical Politics 243.

121 See Human Rights Watch, Tunisia's Repressive Law (Human Rights Watch 2012). We analyze in later chapters how these charters of fundamental rights are accommodated in the new constitutional texts and their possible effectiveness in each post-revolutionary scenario.

122 See Human Rights Watch, 'Egypt' in 'World Report 2011' (Human Rights Watch 2011) 517; see also Human Rights Watch, 'Morocco/Western Sahara' in 'World Report 2011' (Human Rights Watch 2011) 568.

123 Christopher Alexander, 'Authoritarianism and Civil Society in Tunisia' (1997) 27 Middle East Report <http://www.merip.org/mer/mer205/ authoritarianism-civil-society-tunisia> accessed 26 October 2012. 
Ben Ali was pressured to pass a new electoral law, but when adopted it merely allowed the legal opposition parties to share a pitifully small handful of seats. ${ }^{124}$ Ben Ali stepped up his campaign to quash any form of opposition. Some of the methods were coopting and manipulating the press, unions, and other organizations, and the expansion of Tunisia's internal security apparatus. ${ }^{125}$ This repressive strategy elevated the risks of engaging in protest and made collective action much harder to organize and established a climate of fear and intimidation.

\subsection{REVOLUTION AND THE CLAIM OF DEMOCRACY}

We have described the kinds of social contract between the regimes and the populations in some Arab countries, which consist in tolerating repression in exchange for economic welfare. But when the economies did not work, the contractual conditions were altered, the regimes breached their social-contract obligations and therefore, the principle exceptio non rite adiplemti contractus - the rule that a person sued for non-performance of contractual obligations can defend by proving that the plaintiff did not perform its side of the bargain - was applied through the revolution.

The democratic claim deserves a special mention. A democratic system was a common request in the Arab revolutions. It was assumed that through democracy, some of the social and political grievances would be solved. The revolutionary message recognized that the best way to increase the sense of 'engagement' or 'attachment' was to give the demos, not only one small social group, a decisive role in government acts.

After the contractual break, there was no reason to invoke 'Arab exceptionalism', or a particular way to 're-interpret' the theory of democracy that implies the trading of rights and freedoms for economic progress. This exceptionalism had been openly encouraged by Western powers. In the eyes of the United States, the European Union, and other international agents, the limitation of some fundamental rights, undesirable in the abstract, made possible relative social peace and political stability in the region. After the Arab Spring, the recipe was once again that political, social, and economic stability is the necessary starting point

$\begin{array}{ll}124 & \text { Ibid. } \\ 125 & \text { Ibid. }\end{array}$ 
to build a representative democracy. The form of the 'Arab Spring' revolutions leads us to consider a possible linkage between the idea of revolution and the idea of constitutionalism, a topic we introduce here and examine in more detail in Chapter Two.

Democracy has had multiple meanings throughout history. Even today it is an indeterminate concept. We can quote a thousand works and definitions, complementary and contradictory conceptualizations of the term. But democracy, like the eternal return, reappears periodically at the center of the political discourse.

The semantic indeterminacy that affects the term 'democracy' cannot be used to limit its leading position as a main revolutionary claim, or to dismiss the potentialities of a democratic system in the Middle East and North Africa. A second stage of the democratic transformation of the society will determine the involvement of the demos in a constituent process. If indeterminacy is overcome by identifying democracy with both active and passive suffrage, we can say that Egypt, Tunisia, and Libya are already democracies. But that limits the notion of democracy, by ignoring its links with specific political values and with the effectiveness of the most basic human rights.

As our discussion of liberal constitutionalism in the Introduction suggests, another limitation, arguably more defensible, involves the principle of militant democracy. In German constitutional law, militant democracy protects the liberal democratic order (freiheitlichdemokratische Grundordnung). This order is the fundamental basis of the German constitution and describes the basic principles of the moral values and political structures on which the liberal and democratic state of law is established. ${ }^{126}$ The protection is even more important when political parties have consolidated their hegemony in politics and mediated the public constitutional organs. As early as 1934 and 1937 the sociologists Karl Loewenstein and Karl Mannheim were thinking about a democratic construct they called streitbare Demokratie, which can be roughly translated into militant democracy. Their theories, which were based on the undermining of the democracy in the Weimar Republic by the Nazis, were kept in mind during the drafting of the Basic Law. ${ }^{127}$

126 Eckart Thurich, Pocket Politik: Demokratie in Deutschland (Bundeszentrale für Politische Bildung 2011).

127 Karl Mannheim, Diagnosis of Our Time. Wartime Essays of a Sociologist (Psychology Press 1943); Karl Loewenstein, 'Militant Democracy and Fundamental Rights' (1937) 31 The American Political Science Review 417, $423 \mathrm{f}$. 
Militant democracy allows limitations on freedom of speech, political participation, and political pluralism while leaving core values unalterable. The limitation of certain fundamental rights seems to be justified on the basis of the protection of a democratic system. This democratic paradox is generated by two conflicting ideas: the idea that a democracy is based on the free market of ideas, where every party is entitled to express its opinion and to participate in equal conditions to the rest of the parties; and, on the other hand, the idea that a democracy is entitled to defend itself against its enemies. ${ }^{128}$ In some political contexts this constraint is implemented in ways that respect fundamental guarantees. Of course it makes little sense to adopt a theory that limits rights if the political party has no real possibility of threatening the democratic system. To ban the Ku Klux Klan or an Al Qaeda party in the United States would not really make sense. The situation might be different if we are talking about political parties that really can govern and rule the country, such as the F.I.S. in Algeria or the Justice and Development party in Turkey.

Roughly speaking, the concept of 'militant democracy' refers to the fact that political parties cannot use the democratic tools (democratic participation and benefits) to destroy democracy. The theory was initiated after World War II with the decision of the German Federal Constitutional Court of 1952 on the Socialist Reich Party. According to the Court a political party may be removed from the political process only if it rejects the supreme principles of democracy. ${ }^{129}$

A similar theory has been applied in other countries. In some cases the submission of political parties to the democratic standards has been constitutionalized, in others it has been set in an ad hoc law or developed by the judiciary.

In Spain, article 6 of the Constitution requires political parties to have democratic internal structures. The constitutional democratic requirement is spread out to political parties' organization, functioning, and activity with the law on political parties (LOPP). ${ }^{130}$ This norm defines a number

128 Suzie Navot, 'Fighting Terrorism in the Political Arena. The Banning of Political Parties' (2008) 14 Party Politics 746.

129 The connection with democratic values is also displayed in the internal functioning, and if 'a party political organization does not correspond to democratic principles, [we] may conclude that the party plans to impose upon the state the structural principles that it has implemented within its own organization'. Donald P Kommers, The Constitutional Jurisprudence of the Federal Republic of Germany (Duke University Press 1997) 219.

130 LO 6/2002, de 27 de junio, Partidos Políticos. 
of assumptions (article 6) that a political party, in any case, must meet to comply with the requirement of democratic internal functioning.

According to article 9.2 LOPP, a political party may be declared illegal when its activity (carried out repeatedly and gravely) damages 'democratic principles', particularly through pursuing, damaging, or destroying the system of freedom, or through making impossible or eliminating the democratic system. It goes on to state that damaging democratic principles includes systematic violation of fundamental rights and freedoms, or promoting, justifying, or exculpating attacks against the life or safety of persons, or the exclusion or persecution of persons because of their ideology, religion, or beliefs, nationality, race, gender, or sexual orientation. The law also considers as a cause for banning the legitimation, encouragement, or promotion of violence as a method for achieving political goals.

The Spanish law on political parties was enacted to deal with a specific set of problems, and the same happened in Israel. The Supreme Court of Israel has also applied the theory of militant democracy to ban political parties. The arguments used to justify this banning in 1965 elections were confirmed by the Supreme Court. The debate reappeared in 1984 with the extremist right-wing Kach party and the consequent amended section 7 of Basic Law providing that: "A list of candidates shall not participate in elections to the Knesset if its objectives or actions, expressly or by implication, include one of the following: (1) Negation of the State of Israel as a state of the Jewish people. (2) Negation of the democratic character of the State. (3) Incitement to racism'.

But the issue did not end with this regulation, because in 2002 the Knesset enacted an amendment of the section mentioned allowing the disqualification of a party that supported terrorist activities. ${ }^{131}$ Israel provides an interesting tension between the position of the legislature and that of the Court. ${ }^{132}$ The Supreme Court has clarified that banning a party from the political process in Israel would only be approved in extreme, exceptional cases in which there is clear and unequivocal proof of a severe violation of the grounds enumerated in the law. ${ }^{133}$

We have reviewed these versions of the principle of militant democracy to emphasize the extent to which they are in tension with deeper commitments of liberal constitutionalism, and thereby to suggest that the

\footnotetext{
131 Navot (n 128) 750.

132 Ibid 758 .

133 Ibid.
} 
concept of constitutionalism must somehow accommodate more than those commitments alone.

One effort to contain the militant democracy principle is to limit it to extreme cases. So, for example, the European Court of Human Rights (ECtHR) in 1998 (United Communist Party of Turkey v. Turkey) ${ }^{134}$ and in 2009 (Herri Batasuna and Batasuna v. Spain) ${ }^{135}$ remarked that the illegalization of a political party is an extreme preventive measure that only can be applied in necessary cases. Another effort can be found in the German Basic Law, which establishes a specific legal framework to implement the real defense of democracy. Article 1 declares human dignity's inviolability, and human rights as the basis of every community; article 9 states that all associations and clubs need to direct their principles toward the constitution; and article 20 identifies the constitutional principles (The Federal Republic of Germany is a democratic and social federal state) and rights of resistance.

The concept of 'supreme democratic values' cited by the German Constitutional Court, the Israeli Supreme Court, the Spanish law, and the decisions of the ECHR is a vague legal concept. There is no specific list of exactly what these principles are, what to adopt and enforce, and what to require of the political parties. This conceptual vagueness is potentially dangerous for the system, because somehow it could justify judicial activism that would affect the entire political process. And each constitutional system has resolved this legal loophole according to its domestic necessities. The ECHR decision of 2009 narrows the concept of political incompatibility, linking the political parties' activities to the norms of the Convention of Human Rights and to democracy. The Court links the limits of the political party activities to international humanitarian law, and a common and general accepted concept of democracy. This fact really brings theoretical light to a possible application of a theory of militant democracy to the post-revolutionary Arab states, and thereby introduces the possibility of a pluralized concept of constitutionalism, in which the principle of militant democracy exists not as an exception to liberal constitutionalism but rather as part of a variant form of constitutionalism.

The claim of democracy concerns subjects such as political pluralism, universal passive and active suffrage, and a representative electoral system. It is not possible to talk about a democracy when these

134 United Communist Party of Turkey v. Turkey App no 19392/92 (ECtHR 30 January 1998).

135 Herri Batasuna and Batasuna v. Spain App nos 25803/04 and 25817/04 (ECtHR 30 June 2009). 
requirements are absent. Pluralism becomes effective when distinct political forces contribute to the formation and expression of the popular will. Competing political parties are an essential tool for political participation. As we have seen, militant democracy and similar democratic self-defense mechanisms are invoked in countries of different legal families. ${ }^{136}$ And therefore they seem applicable in the new Arab democracies. The Tunisian, Egyptian, and Libyan constituent powers can draft in the constitutional texts the democratic self-defense mechanisms. The role of the Shari'a in cohabitation with constitutional norms cannot be argued as an excuse to deny the constitutional implementation of this theory. We deal with this issue in the next chapter, but as we have seen, there are different legal and jurisdictional possibilities to build up this self-defense mechanism. Germany is a democratic and social federal state; all state authority is derived from the people; the legislature shall be bound by the constitutional order; and all Germans shall have the right to resist any person seeking to abolish the constitutional order.

Again we do not minimize the difficulty of applying this theory to a party that has a good chance of winning national elections, as the Ennadha party did in Tunisia. Perhaps it can establish a red line that no one may cross. Any political party that has won a democratic election must be expected to respect these basic principles, because - as our historical survey showed - a major principle of democracy is not the government of the majority but the respect of minorities.

The Arab Spring has shown that the people of these countries are not so far removed from political issues associated with liberal constitutionalism as some want to suppose. Islam is neither the problem nor the single and unique solution - at least to this point in our argument. After the revolutions, the people of Tunisia, Egypt, and Libya are living a 'founding moment', a moment of politics (Ackerman). If the new governments really want to be considered democratic, as the majority of protesters claimed, they must amplify the voice of the people. If there is an undemocratic founding some of the grievances that led to the Arab Spring will come back again.

\subsection{CONCLUSION}

This chapter developed one of the basic concepts that pervades the essay, namely the revolution as it occurred in the Middle East and North Africa.

136 Markus Thiel (ed), The Militant Democracy Principle in Modern Democracies (Ashgate 2006). 
The starting point has been the analysis of the theoretical reconfiguration of the concept of revolution. Revolutions, as we have seen, do not need violence to be implemented, but - today - precisely the opposite. Information technology and global networks have forced us to reconsider and attempt to update the ancient concept. We have analyzed Arendt's revolutionary features, in an attempt to appraise and update the concept. In so doing, we have linked the 'original' causes of the American and French revolutions with those of the Arab awakening. As a consequence of this revolutionary touch, the chapter followed with the debate between national and popular sovereignty (Sieyès and Condorcet) and its future constitutional accommodation in the Arab post-revolutionary scenarios.

The Arab Spring provoked different kinds of political and doctrinal reactions ranging from an open optimism (for example, Hamid Dabashi) that demands the involvement of doctrinal and political actors in the process, to efforts to demystify the Awakening (for example, Lisa Anderson). Of course we need time to evaluate the real effects of the Arab Spring in each nation. Now, several years after the first revolutionary spark, we can see that some of the main challenges that the post-revolutionary faced have been fulfilled. The conduct of democratic elections, the first ever in Tunisia, Egypt, and Libya, is probably the most notable example. By contrast, we can remark as counterexamples the violence and instability in Libya, sectarian violence and a military coup in Egypt, and the lack of independence of the judiciary in Tunisia, among other bad news. ${ }^{137}$

A revolutionary process always implies a dose of legend, a myth. This effect also happened in the Arab countries, especially in those where the revolution succeeded. As Arendt remarks, this phenomenon occurs in part because of the legend that surrounds the triumph of the political upheaval of the thirteen colonies to break free from the British Empire, and the epic and strong symbolism of the French Third Estate assaulting the

137 See on Egypt Human Rights Watch, 'Egypt: End Mubarak-Era Impunity for Sectarian Violence' Human Rights Watch (New York City, 16 July 2011) $<$ http://www.hrw.org/news/2012/07/16/egypt-end-mubarak-era-impunity-sectarianviolence> accessed 17 March 2015; on the assassination of the U.S. ambassador to Libya, J. Christopher Stevens, see David D Kirkpatrick and Stephen Lee Myers, 'Libya Attack Brings Challenges for U.S.' New York Times (New York City, 12 September 2012) <http://www.nytimes.com/2012/09/13/world/middle east/us-envoy-to-libya-is-reported-killed.html> accessed 17 March 2015; on Tunisia, Clive Baldwin, 'After Ben-Ali's Conviction: the State of Tunisian Justice' Human Rights Watch (New York City, 16 June 2012) <http://www.hrw. org/news/2012/06/16/after-ben-alis-conviction-state-tunisian-justice> accessed 17 March 2015. 
Bastille and liberating the people of the despotic monarchy. ${ }^{138}$ This myth has also imbued the Tahrir Square in Cairo or the cities of Sidi Bouzid in Tunisia or Benghazi in Libya. The myth is also consolidated by the sovereign iconography and the state's propaganda; just think about Eugene Delacroix's world famous oil painting 'Liberty leading the people' or the French Marianne, with the breast exposed representing the motherland. Of course not all the upheavals can be defined as revolutions and not all the revolutions meant Liberté, Égalité, and Fraternité or republican values. But myth has surrounded the Arab revolution. The myth must be transformed into real gains. And the constituent processes and the new constitutions have much to say in order to channel these legal and political improvements. The constituent moment that Tunisia, Egypt, and Libya face is an excellent opportunity to achieve not only political stability, but also a chance to consolidate part of the myth.

Chapter Two analyzes the second main edge of our conceptual framework, the concept of Arab constitutionalism. The chapter is more a legal work, focusing on the concept of Arab legal systems, the role and accommodation of Shari'a within the constitutional drafts, and the relations between constitutions (secular) with the Qur-an (religious).

138 Arendt (n 2) 115. 